\title{
A Lonely and Meaningless Victim--- An Analysis of Addie's Image in As I Lay Dying
}

\author{
Juan Huang ${ }^{1}$, Ling Xiao² \\ ${ }^{1}$ Nanchang Institute of Technology, Nanchang, Jiangxi, 330044,China; \\ ${ }^{2}$ Nanchang Hangkong University Science and Technology Institute, Nanchang, Jiangxi, 330034,China
}

Keywords: As I Lay Dying; a female victim; personality; soul cry

\begin{abstract}
As a central character in William Faulkner's novel As I Lay Dying, Addie is an inner contradiction and a complex character among the underclass women in the southern United States. In work the description on Addie is not much. Faulkner, by means of stream of consciousness, reveals a female victim with lonely soul, along with many characters' demeanors and inner monologues before and after the death of Addie.
\end{abstract}

\section{Introduction}

As I Lay Dying is a novel written by American author William Faulkner who said that he wrote the novel from midnight to 4:00 a.m. over the course of six weeks and that he did not change a word of it. Faulkner wrote it while working at a power plant and published it in 1930.It is Faulkner's fifth novel, consistently ranked among the best novels of the $20^{\text {th }}$ century literature. The story was narrated by 15 different characters over 59 chapters. It is the story of the death of Addie Bundren and her poor, rural family's quest and motivations---noble or selfish---to honor her wish to be buried in her hometown of Jefferson, Mississippi. Addie is the central character and the suffering period of her family is in the process of fulfilling her wishes. As a "human", she was not directly involved in this process, but her whole life was a bumpy and miserable period. Addie was pessimistic, in her view, “To live is to prepare a long sleep”, so her life was meaningless. Continual failures made her heart out of the life --- she longed for love in her inner side but she did not believe in love; she hoped to be understood but she never really opened her heart. It is a tragedy in her life that she never went to face reality with the right attitude, only to lose her life, with no future, no hope, so she ran out of her life in loneliness and despair. The novel revolves around her death and the story happened in a few days before and after "returning to hometown and going to the burial site". The characters in the novel include Addie herself, her husband Anse Bundren, her children, neighbors, etc. The authors described the tense relationship between her and her students, her husband, her children, and the other characters to vividly portray a lonely and painful soul in the numerous contradictions and a female victim crying in the southern.

\section{Addie's characters}

\section{Being honest and hard-working}

The words and deeds of Addie and her family reflect the psychopathic and insane situation of the lower rungs of society in the South of the Unite States and all their strange ridiculous sayings are marked by poverty and ignorance. Addie was a woman as well as a wife, a lover and a mother. Although she was lonely, cold, selfish and mad, to be honest, she was honest and hard-working, with "biased" motherly love. She taught her children that "Fraud is the root of all evils". But because of life force, sometimes she had to do the behavior of fraud. She preferred Jewel in that she got a broken body for the endurance in order to earn money to buy a horse for Jewel, and that she specifically made something good for Jewel, yet she was afraid of being seen by others. The fraud made her have a strong sense of guilt. Meanwhile, Addie was extremely hard-working, which even her husband Anse admitted. 


\section{Being selfish and indifferent}

Addie was selfish and indifferent and her words and deeds were ridiculous and weird, all of which resulted from her hard and monotonous life and her poverty and ignorance caused by her low social status. Asa teacher in primary school, she did not like his career, nor did he like her students. Because she thought that each of them had their own secret and selfish thought and the blood in the body was not the same with each other, of course, was not the same with hers. She always expected that the students would make some mistakes, so that she could whip them. She abandoned them and whipped them psychologically. On the contrary, as a lonely soul, she desired being together with them. By describing the severe tension between her and the students, a victim distorted by reality and tradition stands vividly in front of us. William Faulkner's heroine is a lonely, helpless, almost crazy, selfish and indifferent Addie.

She was so cold to her students. Was she warm to her family members? Only because she can not stand being alone, Addie married Anse. But she did not have any feeling for him. He was excluded from her heart, so her loneliness would not come to an end just because of the marriage. Affected by nihilism, she did not give her real love to her husband, nor did she obtain love in return, and therefore she was lonelier and colder. The marriage without love led to Addie's character being more and more distorted and later she even thought of how to retaliate after her death, which would have her husband continuously suffered by the journey. But Addie herself was tortured when she decided to tell that he would be a great spiritual torment: Addie was not willing to be buried with her husband---she never belonged to him. Addie completely abandoned her husband from her heart, and she thought that Anse was dead.

\section{Being lonely and crazy}

Addie's life is the kind of lower class, hard, lonely and monotonous, which is not so much for her to survive. The selfish indifference appearance wrapped her lonely crazy heart. Loneliness forced her into a strong self-esteem. It is because of self-esteem and loneliness that Addie could never show her despair and sad hearts to others. She rarely communicated with people. In her world, motherhood, love, religion and other values of good and evil were pure words which were meaningless. To her, denying words meant denying all truths and the objective world order posed by language and relationships. So she turned to the lonely craziness. One of her madness behaviors was her fornication and gave birth to Jewel. The purpose of her fornication was to challenge God, got evil, and choosing the priest as the object of fornication made her sins more serious and frightening. For Addie, Jewel was the one God sent to save his people, and it is her "cross". So Addie loved Jewel better than all her other children. But this love is not true maternal love. From the nihilism to loneliness, self-esteem to being proud, and then desire to craziness, Addie is a victim, who was harmed by her father's nihilism and the marriage without love. She lived in a circle of loneliness which led to her crazy imagination and behavior. She tried to get rid of loneliness, but did not find the right approach.

\section{Lacking love and being loved}

One reason for Addie's indifference and craziness is that she lacked love and being loved. Anse bore a great responsibility for her not loving him. Anse was selfish, lazy and cold. Before Addie died, Ansewas unwilling to send a doctor for her. Even when the time came to bury his wife, what he thought is that he could take this opportunity to go into town to make dentures. In Addie's description she admitted that to bury her body forty miles away was a way to revenge Anse. Her death let her get rid of Anse's torture. So Addie is a victim of her husband's indifference. 


\section{Addie's relationships with the people around}

\section{Addie's relations with her children: abnormal and spiritual rule}

What kind of relationship between a mother and her children can lead to her children almost having nothing to do with health and happiness? It is when a woman becomes a mother that she will realize her natural mission because her whole body contributes to the everlasting of the species. But Addie refused this mission and did not want to be a tool for giving birth to children. Any traditional mother is pursuing the fame of a good mother, but she was not just like that for she did not want to have any child and she did not desire to surrender to her physiological fate. Her giving birth to children was just to return them to her husband, so it is not her voluntary choice of having children. Children are no longer priceless and fertility is no longer a sacred function---this cell proliferation became an occasional annoying event. Addie seemed to be a feminist who disgusted abortion and achieved the fate of the body and who would have her own resistance in addition to the nature of maternal love, thus leading to the children in Bundren family lacking love, as if they were against the outside world with silence. Because of their mother's independence, stubbornness, strong character, the children were controlled by the spiritual strength of their mother rather than their father, even after the death of Addie, which seems to be a success of feminist movement.

\section{Addie's relations with her husband: the subversion of "Southern myth"}

Look at the relationship between Addie and her husband. There are two reasons why Addie married: the first and the main reason is that Addie wanted to get rid of a person's loneliness, and she could hear the sound of her body, so all physical, psychological and traditional demands made her find a husband; second, Anse had a farm and a house, which also provided a realistic basis for Addie, shoeing that Addie was a clear-headed woman. Anse, as the Lord of the family was very weak, as a husband, he was without any good. Anse was too weak to do housework and farm work and to bear the responsibility of raising children. On the contrary, Addie had a strong impact on their children and their children more or less inherited the characteristics of Addie. After she had a child, Addie found that Anse had deceived her, in order to retaliate him, she listened to the rebellious cell call in her body and found a lover, which is a common sign of women with flesh and blood and with a sense of awakening and resistance in all the literary works. She no longer believed in the words of Anse. Because language was deceptive, she did not like to speak; it is clear that of fifty-nine chapters, there is inner monologue of Addie in only one chapter. If Addie had not married, she was troubled by physical and mental loneliness and by the traditional customs. But married Addie had the struggle of facing her husband and childbearing, so she was always in torture. Addie began to challenge the designated family position for women designed by the male-dominated southern tradition and in her body some consciousness in a state of repression came to, to subvert the original gender pattern, leading to a state that in the Bundrens, females were strong and males were weak. Old South culture, to a large extent, ignored or did not really consider or fully reproduce the life experience of the South women, so Faulkner described as well as subverted the myth of the South by shaping Addie, which shows that Faulkner is a great writer with complex skills.

\section{Addie's relations with people outside the family: an independent and self-reliant woman}

As the most educated in the novel, Addie committed adultery with the local minister. She was a primary school teacher before marrying Anse, however, she destroyed her image of a good teacher by violence. In the Bundrens, she was the mother of five children and asoul-style character. But Addie, not a traditional rural woman in southern America, was rebellious, pursuing an independent spiritual world and loyal to her inner life. Addie and Whitfield had a passionate love just because Anse could not meet her demand--to be a company to drive away her solitude, nor could he meet her physiological requirements. For her, it is very natural to have an affair with Whitfield---it is a thing which was described by herself flatly, and which Whitfield was afraid to admit. In social life, she was a good wife in the eyes of the neighbors, able to do everything in housework. According to Doctor Peabody, although her body died, Addie, by her soul, still controlled the whole family with her irresistible force. Clearly, Addie was stronger and more independent than the two men. 


\section{Conclusion}

Faulkner arranged Addie's review of her own life on the fifth day after her death, in the middle of the novel, about which the words are not many but with skillful constructing, showing his stream of consciousness on time and space and the highlight of his works---let the soul of the dead complain, cry and let the readers look for the answer from the words of the dead and from the change of the time and space. So, Addie, honest, diligent, indifferent, lonely, crazy and lacking love and being loved, is vivid and standing in front of the readers.

\section{References}

[1] William Faulkner. As I Lay Dying(Translated by Li Wenjun)[M]. Shanghai: Shanghai Translation Publishing House, 2004

[2] Wang Lili. Analyzing Faulkner's Writing Features Fromthe Characters' Psychology in the novel As I Lay Dying[J]. Shandong Literature, 2007 (07)

[3] Wang Xin. Analysis of the Grotesque of Typical Characters in Faulkner's Novels[J].Journal of Jiamusi University (Social Science), 2004 (09)

[4]Zhang Boxiang. Appreciation of English and American Classic Novels[M]. Wuhan: Wuhan University Press, 2005

[5] Zhang Xi. Who is Dying? ---Theme Analysis of William Faulkner'sAs I Lay Dying[J].Journal of Jiangnan University (Humanities and Social Sciences), 2003 (04)

[6]Tong Zhiming. Analysis of narrative styles of William Faulkner's novels with stream of consciousness [J].Journal of Shanghai Electric Power Science College,2004 (03) 